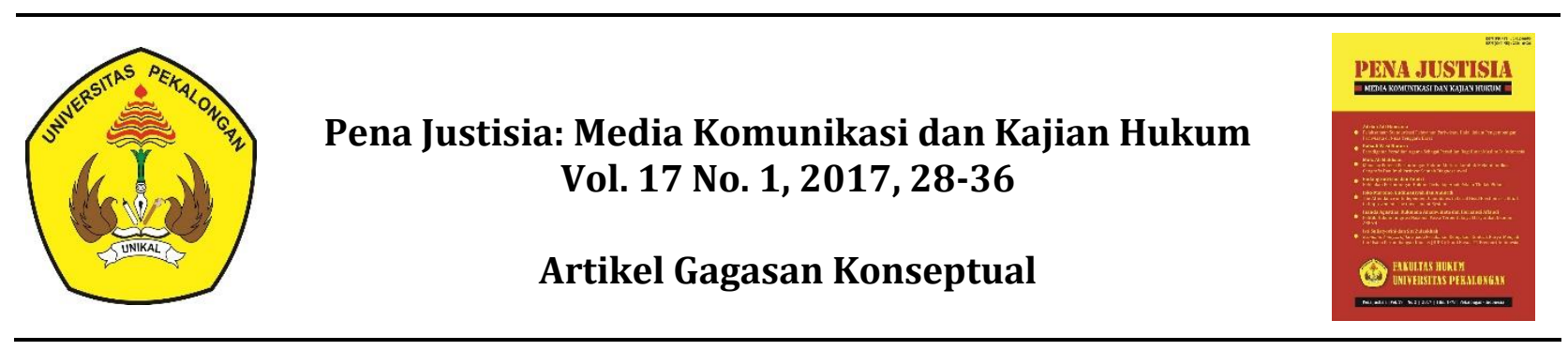

\title{
Hubungan Antara Hukum dan Etika dalam Politik Hukum di Indonesia (Membaca Pancasila sebagai Sumber Nilai dan Sumber Etik)
}

\author{
Sri Pujiningsih
}

Fakultas Hukum Universitas Pekalongan, Indonesia

\section{Artikel Diterima:}

23 April 2017

\section{Artikel Disetujui:}

26 Mei 2017

Artikel Diterbitkan:

10 Juni 2017

Korespondensi Penulis: spningsih.unikal@gmail.com

\begin{abstract}
The purpose of the Indonesian state is contained in the Constitution of 1945 paragraph IV. Achieving the goals together should be designed, formulated and agreed with all the elements of the nation in the teacher called legal politics. The establishment of legal instruments is the final activity of public policy which includes the legislation process. Applied ethics which is a branch of philosophy that discusses about human behavior, in this paper is human in the state. The purpose of this page is to know the relationship between law and how and how to find law and ethics in the Political Law in Indonesia. The legal political formulation was 15 years after independence through the TAP MPRS. 2 of 1960 on the outline of the National Development Plan of the Universe Planning was then changed to State Policy Guidelines (GBHN) which renewed for 5 (five) years. Meanwhile, the relationship between ethics and law can be seen from 3 (three) dimensions, namely the dimension of substance and container, the dimension of relationship breadth shows and the human dimension to realize or violate it.
\end{abstract}

Keywords: Law and Ethics, Political Law, Pancasila

\section{Abstrak}

Tujuan negara Indonesia tertuang dalam pembukaan Undang-undang Dasar 1945 alinea IV. Pencapaian tujuan bersama tersebut harus dirancang, dirumuskan dan disepakati bersama seluruh elemen bangsa yang dalam kebiasaan akademik disebut sebagai politik hukum. Pembentukan kaedah hukum merupakan kegiatan final dari kebijakan publik yang didalamnya memuat proses legislasi. Etika terapan yang merupakan cabang filsafat yang membahas tentang perilaku manusia, dalam artikel ini perilaku manusia dalam bernegara. Tujuan tulisan ini adalah untuk mengetahui hubungan antara hukum dengan etik dan bagaimana kedudukan hubungan hukum dan etik dalam Politik Hukum di Indonesia. Rumusan politik hukum sudah 15 tahun setelah kemerdekaan melalui TAP MPRS No. 2 tahun 1960 tentang Garis-garis Besar Pola Pembangunan Nasional Semesta Berencana kemudian dirubah menjadi Garis-Garis Besar Haluan Negara (GBHN) yang diperbarui selama 5 (lima) tahun sekali. Sementara itu, hubungan antara etika dengan hukum bisa dilihat dari 3 (tiga) dimensi yakni dimensi substansi dan wadah, dimensi hubu-ngan keluasan cakupannya serta dimensi alasan manusia untuk mematuhi atau melanggarnya.

Kata kunci: Hukum dan Etika, Politik Hukum, Pancasila 


\section{PENDAHULUAN}

Secara historis-sosiologis, manusia Indonesia berasal dari Mekhong-Vietnam yang karena sesuatu hal menyebar ke pulau-pulau nusantara. Berangkat dari fakta sejarah ini, maka yang tumbuh dan berkembang adalah kebudayaan etnik yang terpencar-pencar. Jadi pertumbuhan ke arah rasa persatuan yang lebih besar tentang kepentingan bersama jelas terhalang oleh perbedaan bahasa, adat istiadat, alam lingkungan, juga kepercayaan dan agama, bentuk tubuh, warna kulit dan sebagainya, ringkasnya tergantung pada besarnya pluralitas masyarakat. Namun demikian secara politis-yuridis bangsa Indonesia telah berhasil menciptakan integritas nasional melalui sumpah pemuda pada tahun 1928. Kumpulan dari berbagai bangsa yang membentuk nation bersama bernama Indonesia. Kamus Besar Bahasa Indonesia (KBBI) mengartikan bangsa sebagai kelompok masyarakat yang bersamaan asal keturunan, adat, bahasa dan sejarahnya serta berpemerintahan sendiri. Konsep KBBI tentang bangsa ini selaras dengan teori terjadinya negara secara primer pada fase genootschap terjadi perkelompokan dari orang-orang yang menggabungkan dirinya untuk kepentingan bersama dan disandarkan pada persamaan. Untuk hal ini, kepemimpinan dipilih secara "primus inter pares" atau yang terkemuka diantara unsur yang sama. Persamaan dan kepentingan bersama inilah yang disebut sebagai unsur bangsa.

Kumpulan orang dalam berbagai bangsa dan memiliki tujuan yang sama tersebut membentuk suatu negara. Sebagaimana dikemukakan oleh para pendiri negara ini, tujuan negara Indonesia tertuang dalam pembukaan Undang-undang Dasar 1945 alinea IV yang terdiri atas: melindungi segenap bangsa Indonesia dan seluruh tumpah darah Indonesia, memajukan kesejahteraan umum, mencerdaskan kehidupan bangsa dan ikut melaksanakan ketertiban dunia berdasarkan kemerdekaan, kedamaian abadi, dan keadilan sosial,
Pencapaian tujuan bersama tersebut harus dirancang, dirumuskan, dan disepakati bersama seluruh elemen bangsa yang dalam kebiasaan akademik disebut sebagai politik hukum. Meramu antara tujuan yang akan dicapai dengan penentuan kaidah dalam mencapai tujuan tersebut. Sistem yang berlaku di Indonesia menetapkan bahwa perancangan tujuan melalui intstrumen hukum sangat dipengaruhi oleh kekuatan-kekuatan politik melalui percaturan kepentingan partai yang akan membentuk produk hukum tersebut. Pertarungan atau percaturan kepentingan melalui partai-partai politik tersebut menurut Mahfud MD menghasilkan 2 (dua) pilihan, yakni melalui kompromi politik atau melalui dominasi politik. Dominasi politik terjadi apabila pertarungan diwarnai oleh kekuatan politik yang terbesar. Pilihan melalaui kompromi politik tidak dijelaskan dalam konteks ini, tetapi penuis berpendapat bahwa pilihan atas kompromi politik terjadi apabila partai politik beragam dan kekuatan posisi tawar (beragaining position) relatif seimbang. ${ }^{1}$ Sejalan dengan pandangan Mahfud MD, Satjipto Rahardjo mengakui hanya pilihan tunggal yakni bahwa proses-proses pembuatan hukum lebih memperlihatkan dominasi pengambilan keputusan politik. Proses pembuatan hukum sebenarnya melibatkan para ahli hukum namun hanya diposisikan sebagai pihak yang memberikan masukan-masukan dalam rangka menyususn kerangka permasalahan dan tidak dalam rangka memecahkan persoalan. ${ }^{2}$ Pembentukan kaedah hukum dalam pandangan B.Hestu Cipto Handoyo merupakan kegiatan final dari kebijakan publik yang didalamnya memuat proses legislasi. Output dari kegiatan tersebut adalah peraturan perundang-undangan (UU) dibuat untuk disahkan sehingga kebijakan publik tersebut mengikat secara umum. Proses legislasi tersebut adalah tempat pertarungan dan pertemuan kepentingan politik setiap kelompok politik yang ter-

2 Satjipto Rahardjo , 2006, Membedah hukum progresif. Pengarang. Jakarta: Penerbit Buku Kompas, hlm. 23 
gabung dalam partai politik, kepentingan pihak asing maupun kepentingan masyarakat sipil.

Etika terapan yang merupakan cabang filsafat yang membahas tentang perilaku manusia, dalam artikel ini perilaku manusia dalam bernegara. Sebagaimana dipahami, salah satu karakter berfikir secara filsafat adalah kritis, karena terkait dengan etika terapan, maka kita dituntut untuk berfikir atau bersikap kritis terhadap pola-pola umum yang berlaku dalam masyarakat. Pola umum dalam tulisan ilmiah ini adalah politik hukum yang berlaku di Indonesia saat ini. Tulisan ini mengkaji mengenai hubungan antara Hukum dengan Etika dalam Politik Hukum di Indonesia.

\section{RUMUSAN MASALAH}

Berdasarkan latar belakang masalah tersebut di atas, dirumuskan permasalahan sebagai berikut: Pertama, apakah terdapat hubungan antara hukum dengan etik; Kedua, bagaimana kedudukan hubungan hukum dan etik dalam Politik Hukum di Indonesia.

\section{PEMBAHASAN}

\section{Hubungan Antara Etika dan Moral}

Moral berkaitan dengan tingkah laku manusia yang dapat diukur dari sudut baik maupun buruk, sopan ataupun tidak sopan, susila atau tidak susila. ${ }^{3}$ Etika berkaitan dengan dasar-dasar filosofis dalam hubungan dengan tingkah laku manusia. dengan pandangan hidup, serta filsafat hidup dari masyarakat tertentu .4

Moral merupakan suatu ajaran-ajaran atau wejangan-wejangan, patokan-patokan, kumpulan peraturan, baik lisan maupun tertulis tentang bagaimana manusia harus hidup dan bertindak agar menjadi manusia yang baik. Etika adalah suatu cabang filsafat yaitu suatu pemikiran kritis dan mendasar tentang ajaran-ajaran dan pandanganpandangan moral tersebut. Etika adalah ilmu

3 Kaelan, 2013, Negara Pancasila Kultural, Historis, Filosofis, Yuridis, dan Aktualisasinya, Cetakan Pertama, Yogyakarta : Paradigma, 436.

4 Ibid, hlm. 438-439 pengetahuan yang membahas prinsip-prinsip moralitas $^{5}$

Setiap orang memiliki moralitasnya sendiri, tetapi tidak sedemikian halnya dengan etika. Tidak semua orang perlu melakukan pemikiran yang kritis terhadap etika. Terdapat suatu kemungkinan bahwa seseorang mengikuti begitu saja pola-pola moralitas yang ada dalam suatu masyrakat tanpa perlu merefleksikannya secara kritis. ${ }^{6}$

Sebagaimana diketahui, disiplin etik pada mulanya bersumber pada doktrin-doktrin agama, namun dalam perkembangannya, seiring dengan perkembangan masyarakat, komunitas tersebut juga mulai memikirkan dan merasa memerlukan batasan baik dan buruk atas perilaku anggotanya. Ketentuan baik dan buruk ini digunakan sebagai acuan atau patoka $\mathrm{n}$ dalam mengarahkan perilaku setiap warga. Untuk memperkuat penjelasan ini perlu ditelusuri pengertian etika sehingga menjadi jelas dalam menangkap makna etika dalam kajian ini.

Etik berasal dari bahasa Yunani "ethos" yang berarti watak atau adat dan asal kata moral yang sama artinya dengan kata etik dari bahasa Latin "mos" untuk tunggal dan jamaknya "mores" yang juga berarti adat atau cara hidup. Dari kedua perkataan tersebut, etik dan moral menunjukkan cara berbuat yang menjadi adat karena persetujuan atau praktek sekelompok manusia. Jadi moral dan moralitas dipakai untuk perbuatan yang sedang dinilai, sedangkan etik dipakai untuk pengkajian sistem nilai-nilai atau kode. ${ }^{7}$ Dalam pandangan Jimly Asshiddiqie, etika atau ethics merupakan suatu cabang filsafat yang memperbincangkan tentang perilaku benar (right) dan baik (good) dalam hidup manusia. Filsafat etik tidak hanya menaruh soal pada benar dan salah, tetapi lebih dari itu, mencakup persoalan baik dan buruk.Tujuan utamanya adalah kehidupan yang

\footnotetext{
Ibid. hlm. 444

Ibid. hlm. 455

M. Said, 1976, Etik Masyarakat Indonesia, Jakarta : Pradnya Paramita, hlm. 23-24
} 
baik bukan sekedar kehidupan yang selalu benar atau tidak pernah salah. ${ }^{8}$

\section{Tahap Perkembangan Etika}

Sebagaimana telah dikemukakan dalam pembahasan sebelumnya, etika berasal dari doktrin agama yang bersandar pada keyakinan dan karenanya bersifat abstrak. Namun kebutuhan akan pengendalian dan pengarahan perilaku manusia membutuhkan perubahan pemberlakuan etika dari yang semula hanya bersifat himbauan melalui khutbah-khutbah menjadi konkrit atau nyata melalui teguran, peringatan yang berujung dengan penerapan sanksi atas penyimpangan perilaku tersebut. Secara historis dan perkembangan ilmu pengetahuan, sistem etika berkembang melalui 5 (lima) tahapan. ${ }^{9}$

Tahap pertama, etika teologi (theogical ethics), asal mula etika yang berasal dari dokrtin agama. Kedua, etika ontologis (ontological ethics) yang merupakan tahap perkembangan dari etika agama. Etika dikembangkan dari doktrin abstrak menjadi hasil pemikiran spekulasi dan dijadikan salah satu objek kajian filsafat. Sebagai salah satu kajian filsafat, sistem filsafat etik berkembang menjadi 4 (empat) sub sistem berupa descriptive ethics yakni etika yang berkenaan dengan perilaku benar dan baik sebagaimana dipikirkan orang, normative atau prescriptive ethics yakni etika yang berkenaan dengan perilaku yang dinilai sudah seharusnya dilakukan, applied ethics yakni etika yang berkenaan dengan pengetahuan tentang moral dan bagaimana pengetahuan itu diwujudkan dalam praktik, dan meta ethics yakni membahas mengenai apa yang dimaksud dengan benar dan baik itu sendiri. ${ }^{10}$ Ketiga, positivasi etik berupa kode etik (code of ethics) dan pedoman perilaku ( code of conduct) yakni pedoman perilaku yang lebih konkrit. Keempat, etika fungsional tertutup (close functional ethics) dimana proses

\footnotetext{
Jimly Asshiddiqie, 2016, Peradilan Etik dan Etika Konstitusi, Jakarta: PT. Sinar Grafika, hlm.42

$9 \quad$ Ibid. hlm. $\mathrm{x}$

10 Ibid, hlm. 43

11 Padmo Wahjono, 1986, Indonesia Negara Berdasarkan atas Hukum, Cet. II, Jakarta: Ghalia Indonesia, hlm.160
}

peradilan etik dilakukan di internal komunitas/organisasi secara tertutup, dan Kelima, etika fungsional terbuka (open functional ethics) dalam bentuk peradilan etika yang bersifat terbuka.

\section{Pengertian Politik Hukum}

Beberapa ahli mengartikan politik/pembaharuan/pembangunan hukum sebagai berikut:

Pertama, Padmo Wahjono. Politik hukum didefinisikan sebagai kebijakan dasar yang menentukan arah, bentuk maupun isi dari hukum yang akan dibentuk. Kemudian, Padmo mendefinisikan arti tersebut secara lebih konkrit sebagai kebijakan penyelenggara negara tentang apa yang dijadikan kriteria untuk menghukumkan sesuatu. ${ }^{11}$

Kedua, Teuku Mohammad Radhie. Politik hukum diartikan sebagai suatu pernyataan kehendak penguasa negara mengenai hukum yang berlaku di wilayahnya, dan mengenai arah perkembangan hukum yang akan dibangun. ${ }^{12}$

Ketiga, Soedarto. Politik hukum adalah kebijakan negara melalui badan-badan negara yang berwenang untuk menetapkan peraturan-peraturan yang dikehendaki yang diperkirakan akan digunakan untuk mengekspresikan apa yang terkandung dalam masyarakat dan untuk mencapai apa yang dicita-citakan. Soedarto juga mengartikan politik hukum sebagai usaha untuk mewujudkan peraturan-peraturan yang baik sesuai dengan keadaan dan situasi pada suatu waktu. ${ }^{13}$

Keempat, Satjipto Rahardjo. Politik berkaitan dengan pemilihan tujuan diantara berbagai tujuan yang mungkin sedangkan hukum harus senantiasa melakukan penyesuaian terhadap tujuan-tujuan yang ingin dicapai oleh masyarakatnya, dengan demikian hukum memiliki dinamika. Politik hukum diartikan sebagai keharusan untuk menentukan suatu pilihan mengenai tujuan

12 Jurnal Prisma Nomor 6 Tahun II Desember 1973, Pembaharuan dan Politik Hukum dalam Pembangunan Nasional, hlm.4

13 Soedarto, 1986, Hukum dan Hukum Pidana, Bandung: Alumni, hlm. 151 
maupun cara-cara yang hendak dipakai untuk mencapai tujuan tersebut. ${ }^{14}$

Politik hukum merupakan salah satu faktor yang menyebabkan terjadinya dinamika yang demikian itu karena ia diarahkan ius constituendum, hukum yang seharusnya berlaku. Menurut Satjipto, studi politik hukum menimbulkan beberapa pertanyaan terkait tujuan sistem hukum yang ada, cara mencapai tujuan, waktu perubahan hukum berikut cara melakukan perubahan, kemungkinan perumusan pola yang mapan, perubahan dilakukan secara total atau bagian demi bagian. ${ }^{15}$

Kelima, C.F.G. Soenaryati Hartono. Politik Hukum dimaknai sebuah alat (tool) atau sarana atau langkah yang dapat digunakan oleh pemerintah untuk menciptakan sistem hukum nasional yang dikehendaki dan dengan sistem hukum nasional itu akan diwujudkan cita-cita bangsa Indonesia. ${ }^{16}$

Keenam, Abdul Hakim Garuda Nusantara. Abdul Hakim Garuda Nusantara mendefinisikan politik hukum nasional sebagai kebijakan hukum yang hendak diterapkan atau dilaksanakan secara nasional oleh suatu pemerintahan negara tertentu. Bentuk implementasi politik hukum nasional mencakup : (1) pelaksanaan ketentuan hukum yang telah ada secara konsisten, (2) pembangunan hukum yang intinya adalah pembaharuan terhadap hukum yang telah ada dan dianggap usang, dan penciptaan hukum baru yang diperlukan untuk memenuhi tuntutan perkembangan yang terjadi dalam masyarakat, (3) penegasan fungsi lembaga penegak atau pelaksana hukum dan pembinaan anggotanya, dan (4) meningkatkan kesadaran masyarakat menurut persepsi kelompok elit pengambil kebijakan. ${ }^{17}$

14 Satjipto Rahardjo, 2006, Ilmu Hukum, Cetakan keenam, Bandung: Alumni, hlm. 358

15 Satjipto Rahardjo, 2006, Ilmu Hukum, Cetakan keenam, Bandung: Alumni, hlm. 358-359

16 C.F.G. Sunaryati Hartono, 1991, Politik Hukum Menuju Satu Sistem Hukum Nasional, Bandung: Alumni, hlm.1

17 Abdul Hakim Garuda Nusantara, "Politik Hukum Nasional", makalah disampaikan pada Karya Latihan Bantuan Hukum
Ketujuh, Mochtar Kusumatmadja. Pandangan Mochtar Kusumaatmadja tentang pembangunan hukum berpangkal pada cara berfikir masyarakat Indonesia tentang hukum. Di satu sisi, orang hilang kepercayaan terhadap hukum, tetapi di lain pihak masyarakat pada umumnya memiliki kepercayaan yang naif terhadap kekuatan yang seakan-akan magis re ligius dari hukum. Berdasarkan argumentasi tersebut, maka pembangunan nasional adalah masalah pembaharuan cara berfikir, sikap hidup, sifat, dan nilai-nilai. Tanpa sikap dan cara berfikir yang berubah pengenalan lembaga-lembaga moderen dalam kehidupan tidak akan berhasil. ${ }^{18}$

Kedelapan, Siti Soetami. Pembinaan hukum artinya tidak saja membuat yang baru, tetapi juga menyesuaikan hukum yang ada di masyarakat.Hukum yang akan disusun adalah hukum yang moderen, bertujuan meningkatkan kemampuan sesuai kebutuhan yang memiliki ciri-ciri : konsentris artinya adanya satu tangan yang mengatur/membuat yaitu pengundang-undang, konvergen artinya hukum Indonesia bersifat terbuka terhadap perubahan dan perkembangan, dan tertulis untuk lebih menjamin kepastian hukum. ${ }^{19}$

Kesembilan, Mahfud MD. Mahfud MD merumuskan politik hukum sebagai legal policy atau (kebijakan) resmi tentang hukum yang akan diberlakukan, baik dengan pembuatan hukum baru maupun dengan penggantian hukum lama, dalam rangka mencapai tujuan negara sebagaimana tercantum didalam Pembuakaan UUD 1945. ${ }^{20}$

Kesepuluh, Imam Syaukani dan A.Ahsin Thohari. Politik hukum didefinisikan sebagai kebijakan dasar penyelenggaraan negara dalam proses perumusan, pembentukan, dan pengembangan hukum yang akan, sedang, dan telah berlaku, yang bersumber dari nilai-nilai yang

(Kalabahu), diselenggarakan Yayasan LBH Indonesia dan LBH Surabaya, September 1985

18 Mochtar Kusumaatmaja, 2006, Konsep-konsep dalam Pembangunan Hukum, Cetakan kedua, Bandung: Alumni, hlm.1

19 Siti Soetami, Pengantar Tata Hukum Indonesia, Cetakan kujuh, Bandung: Refika Aditama, hlm.7

20 Moh.Mahfud MD, 2014, Politik Hukum di Indonesia, Cetakan keena m, Jakarta: Rajawali Press, hlm.1 
berlaku di masyarakat untuk mencapai tujuan negara yang dicita-citakan.

Kesebelas, Ahmad M. Ramli. Politik hukum adalah arah yang ditempuh dalam pembuatan dan penegakkan hukum untuk mencapai cita-cita dan tujuan bangsa. ${ }^{21}$

Berdasarkan pendapat 11 (sebelas) ahli hukum tersebut setidak-tidaknya terdapat tiga ciri yang sama dalam politik hukum yakni kebijakan dasar yang memuat arah kemana hukum akan dibawa, dibuat oleh penguasa (pihak berwenang), pembuatan hukum dilakukan dengan cara memilih nilai-nilai yang berkembang di masyarakat yang disepakati bersama dan kemudian dituangkan dalam norma untuk mengkaidahi perilaku bersama, dan bersifat constituendum yang memuat hukum ideal atau cita hukum yang akan diberlakukan. Terlepas dari kelima persamaan tersebut, terdapat beberapa aspek politik hukum yang bersifat khusus dari pengertian yang di sampaikan para ahli tersebut diantaranya apa yang disampaikan oleh Mochtar Kusumaatmaja yang tidak dikemukakan oleh ahli hukum lain. Mochtar lebih menekankan bahwa pembangunan hukum atau politik hukum sama dengan pembaharuan cara berfikir, sikap, dan nilai-nilai yang berkembang di masyarakat. Penulis menafsirkan bahwa pendapat Mochtar Kusumaatmaja didasark an atas alasan penggerak terjadinya pembangunan hukum. Selain itu, Siti Soetami juga memiliki pandangan yang berbeda dimana salah satu hal dalam politik hukum adalah adanya keharusan hukum tertulis untuk menjamin kepastian hukum. Perbedaan pandangannya dipahami dalam konteks pembuatan hukum yang merupakan kesepakatan bersama dimana kewenangannya diberikan kepada pengundang-undang.

Melalui tulisan ini, penulis menyimpulkan bahwa politik hukum merupakan sikap untuk memilih apa-apa yang berkembang dimasyarakat, kemudian dipilih sesuai dengan prioritas dan diselaraskan dengan konstitusi kita (UUD 1945) dan kemudian dituangkan dalam produk hukum.
Kebijakan dasar yang memuat arah harus direncanakan dengan baik. Perencanaan tersebut dilakukan oleh Badan Pembangunan Hukum Nasional (BPHN) didirikan pada 1958 atau 13 tahun setelah Indonesia merdeka. Pada tahun 1970, Enambelas tahun kemudian yakni pada tahun 1976, gagasan tentang pembangunan hukum melalui sebuah perencanaan dimulai dan menurut penulis gagasan pembangunan hukum terencana inilah yang hakikatnya sebagai cikal-bakal munculnya Program Legislasi Nasional (Prolegnas) yang dalam perjalanan sejarahnya mengalami dinamika. Satu tahun kemudian (tahun 1977) BPHN untuk pertama kalinya menyusun Prolegnas secara terencana dan koordinatif. Fungsi Prolegnas mendapatkan penegasan melalui Surat Keputusan Menteri Kehakiman Nomor : M-PR.02.08-41, tertanggal 26 Oktober 1983 yang berisi pembentukan Panitia Kerja Tetap Program Legislasi Nasional (Pranjatap Prolegnas). Pengembanan tugas BPHN sebagai Perencana Pembangunan Hukum Nasional mendapatkan status hukum yang lebih kuat melalui penerbitan Keputusan Presiden Nomor 32 tahun 1988. Keppres tersebut memberi wewenang tentang Penyusunan daftar Prolegnas yang dilakukan oleh Tim Kerja Antardepartemen dan didukung oleh Tim Kerja BPHN.

Meskipun demikian, proses atau mekanisme penyusunan peraturan perundang-undangan telah jauh diatur sebelum gagasan BPHN dan untuk pertama kalinya diatur melalui Instruksi Presiden No. 15 tahun 1970 yang kemudian dirubah melalui Keppres No.188 tahun 1998 tentang Tata Cara Mempersiapkan Rancangan Undang-Undang yang dilengkapi dengan Keppres No. 44 tahun 1999 tentang Teknik Penyusunan Perundang-undangan dalam bentuk RUU, RPP, dan Keppres. Berdasarkan rangkaian pengaturan tersebut, penulis berpendapat bahwa Prolegnas telah ada sejak tahun 1970 .

Amandemen pertama UUD 1945 pada tahun 1999 menggeser pembentukan UU ke DPR dengan ketentuan, BPHN selaku wakil pemerintah

\footnotetext{
21 BPHN, 2008, TIGA DEKADE BPHN, Jakarta :BPHN, hlm. vii
} 
membidangi Prolegnas sebagai proram perencana pembangunan hukum dan DPR melalui pembentukan Badan Legislasi (Baleg) yang membidangi perencanaan dan penyusunan program usulan program prioitas pembahasan RUU.

Pada tahun 2000, kegiatan Prolegnas menjadi bagian dari Program Pembangunan Nasional (Propenas) yang dibentuk dengan undangundang. Melalui mekanisme ini, prioritas pembentukan peraturan perundang-undangan menjadi bagian yang tidak terpishkan dari Propenas. Prolegnas sebagai bagian dari Propenas mendapatkan landasan hukum yang kuat dengan diterbitkannya Undang-Undang No. 10 tahun 2004 sebagaimana telah diubah dengan Undang-undang Nomor 12 tahun 2011 tentang Pembentukan Peraturan Perundang-undangan. Pembuatan peraturan perundang-undangan dibatasi sedemikian rupa melalui tahapan perencanaan, persiapan, teknik penyusunan, perumusan, pembahasan, pengesahan, pengundangan, dan penyebarluasan. Dengan demikian dapat dikatakan bahwa hubungan antara peraturan perundang-undangan tentang tata cara pembentukan peraturan perundangundangan, Prolegnas dan BPHN adalah peraturan berkedudukan sebagai dasar pijakan, Prolegnas sebagai dokumen perencanaan sedangkan BPHN adalah lembaga yang mewakili pemerintah dalam menentukan arah kebijakan hukum. Peraturan memberikan rambu-rambu atau kaedah-kaerah, Prolegnas sebagai tempat menampung rencanarencana hukum dan BPHN sebagai motor dalam perencanaan maupun pembangunan hukum tersebut.

\section{Hubungan Hukum dan Etika dalam Politik Hu- kum di Indonesia}

Hubungan antara etika dengan hukum bisa dilihat dari 3 (tiga) dimensi yakni dimensi substansi dan wadah, dimensi hubungan keluasan cakupannya serta dimensi alasan manusia untuk mematuhi atau melanggarnya. Ketiga dimensi ini saya ringkas dari pendapat beberapa ahli hukum yang memiliki perhatian khusus terhadap etik.

Jimly Asshiddiqie, mengibaratkan hubungan antara hukum dengan etika dengan memberi catatan agama sebagai ruh/jiwa dari kedua hal tersebut dengan ilustrasi nasi bungkus, hukum sebagai bungkusnya, nasi beserta lauknya adalah etikanya, dan zat protein, vitamin , dan unsur-unsur terkandung lainnya sebagai agama yang merupakan asal-usul dari keduanya (etika dan hukum). Dimensi ketiga cakupan luasan atas hubungan etik dan hukum dimana etika lebih luas dari hukum, karena itu setiap pelanggaran hukum pasti merupakan pelanggaran etik, singkat kata pelanggaran hukum adalah pelanggaran etik. Namun tidak demikian sebaliknya, pebuatan yang dianggap meanggar etik belum tentu melanggar hukum. ${ }^{22}$ Jika etika diibaratkan sebagai samudera maka kapalnya adalah hukum sebagaimana ditegaskan Ketua Mahkamah Agung Earl Warren.. "Law floats in the sea of ethics". ${ }^{23}$

Paulus Harsono mensitir tentang dimensi ketiga ini, terkait kedudukan etika dimana etika juga berhubungan dengan hukum dalam hal bagaimana manusia mempertimbangkan untuk mematuhi peraturan dan kewajiban;tetapi dipatuhinya hukum serta peraturan dan kewajiban itu bukan karena takut akan dikenai sanksi, tetapi karena kesadaran diri bahwa hukum serta peraturan dan kewajiban tersebut baik dan perlu dipenuhi oleh dirinya sendiri. Masih relevan dengan pandangan Paulus Harsono, dalam hal perilaku manusia, etika berfungsi sebagai pagar preventif atas perilaku baik dan buruk sebelum perilkau menjangkau ketentuan benar dan salah yang merupakan fungsi pagar perilaku bagi hukum. Dengan demikian, perilaku menyimpang manusia harus melewati sistem etika yang berfungsi sebagai koreksi dan sebisa mungkin tidak perlu memasuki mekanisme hukum dalam penyelesaian penyimpangan perilaku manusia tersebut. 
Dikaitkan dengan perilaku etik para pemangku jabatan-jabatan publik dan profesional yang sangat mengandalkan kepercayaan publik, pengendalian perilaku melaui sistem etika patut dipertimbangkan. Alasannya, apabila penyelesaian masalah penyimpangan perilaku para pejabat publik selama ini langsung menggunakan pendekatan hukum, maka organisasi publik langsung terkikis kepercayaannya sejalan dengan berlangsungnya proses hukum.

\section{Letak Politik Hukum}

Siti Soetami dengan mengadopsi pengertian politik hukum Teuku Mohammad Radhie, berpendapat bahwa secara tegas tentang dimana politik hukum dimuat dijumpai pada Pasal 102 UUDS 1945 yang berbunyi :

Hukum perdata dan hukum dagang, hukum pidana sipil maupun hukum pidana militer, hukum acara pidana, susunan dan kekuasaan pengadilan, diatur dengan undang-undang dalam kitab-kitab hukum, kecuali jika pengundang-undang menganggap perlu untuk mengatur beberapa hal dan undang-undang tersendiri.

Dekrit Presiden 5 Juli 1959 dengan sendirinya yang menyatakan kembali ke UUD 1945 UUDS 1950 menjadi tidak berlaku. Rumusan politik hukum sejak tahun tersebut vacum.Baru pada tahun 1973, MPR berhasil menghasilkan ketetapan Nomor IV/MPR/73 tentang Garis-Garis Besar Haluan Negara yang didalamnya secara resmi dan tegas digariskan politik hukum Pemerintah RI. Melalui mekanisme GBHN ini, politik hukum diperbaharui selama 5 tahun sekali. ${ }^{24}$

Apabila ditelusuri, rumusan politik hukum sudah 15 tahun setelah kemerdekaan melalui TAP MPRS No. 2 tahun 1960 tentang Garis-garis Besar Pola Pembangunan Nasional Semesta Berencana (GBPNSB) berlaku 9 (sembilan tahun) dan kemudian dirubah menjadi Garis-Garis Besar Haluan Negara (GBHN) yang diperbarui selama 5 (lima) tahun sekali.

24 Siti Soetami, 2007, Pengantar Tata Hukum Indonesia, Edisi Revisi, PT. Refika. Aditama, Bandung, hlm. 3-4

\section{PENUTUP}

Politik hukum merupakan sikap untuk memilih apa-apa yang berkembang dimasyarakat, kemudian dipilih sesuai dengan prioritas dan diselaraskan dengan konstitusi kita (UUD 1945) dan kemudian dituangkan dalam produk hukum. Rumusan politik hukum sudah 15 tahun setelah kemerdekaan melalui TAP MPRS No. 2 tahun 1960 tentang Garis-garis Besar Pola Pembangunan Nasional Semesta Berencana (GBPNSB) berlaku 9 (sembilan tahun) dan kemudian dirubah menjadi Garis-Garis Besar Haluan Negara (GBHN) yang diperbarui selama 5 (lima) tahun sekali.

Sementara itu, hubungan antara etika dengan hukum bisa dilihat dari 3 (tiga) dimensi yakni dimensi substansi dan wadah, dimensi hubungan keluasan ca-kupannya serta dimensi alasan manusia untuk mematuhi atau melanggarnya.

\section{DAFTAR PUSTAKA}

Mahfud MD, Moh. 2012. Politik Hukum Di Indonesia. Jakarta: PT Raja Grafindo;

Rahardjo, Satjipto. 2006. Membedah hukum progresif. Jakarta: Penerbit Buku Kompas;

Kaelan. 2013. Negara Pancasila Kultural, Historis, Filosofis, Yuridis, dan Aktualisasinya, Cetakan Pertama. Yogyakarta: Paradigma;

M. Said. 1976. Etik Masyarakat Indonesia. Jakarta: Pradnya Paramita;

Asshiddiqie, Jimly. 2016. Peradilan Etik dan Etika Konstitusi. Jakarta: PT. Sinar Grafika;

Wahjono, Padmo. 1986. Indonesia Negara Berdasarkan atas Hukum. Cet. II, Jakarta: Ghalia Indonesia;

Soedarto. 1986. Hukum dan Hukum Pidana, Bandung: Alumni;

Rahardjo, Satjipto. 2006. Ilmu Hukum. Cetakan keenam. Bandung: Alumni;

Hartono, C.F.G. Sunaryati. 1991. Politik Hukum Menuju Satu Sistem Hukum Nasional. Bandung: Alumni;

Nusantara, Abdul Hakim Garuda. "Politik Hukum Nasional". Makalah disampaikan pada 
Karya Latihan Bantuan Hukum (Kalabahu), diselenggarakan Yayasan LBH Indonesia dan LBH Surabaya, September 1985

Kusumaatmaja, Mochtar. 2006. Konsep-konsep dalam Pembangunan Hukum. Cetakan kedua. Bandung: Alumni;

Soetami, Siti. 2007. Pengantar Tata Hukum Indonesia, Cetakan kujuh, Bandung: Refika Aditama, 